\title{
EFFECT OF SOFT STOREYS IN EARTHQUAKE RESISTANT ANALYSIS OF RC FRAMED STRUCTURES
}

\author{
Abdul Rauf Muqeeb ${ }^{1}$, Md Faisaluddin ${ }^{2}$, Shaik Abdulla ${ }^{3}$ \\ ${ }^{1}$ Post Graduate Student, Civil Engineering Department, Khaja Banda Nawaz College of Engineering, Gulbarga, \\ Karnataka, India \\ ${ }^{2}$ Professor, Civil Engineering Department, Khaja Banda Nawaz College of Engineering, Gulbarga, Karnataka, India \\ ${ }^{3}$ Professor, Civil Engineering Department, Khaja Banda Nawaz College of Engineering, Gulbarga, Karnataka, India
}

\begin{abstract}
As per the codal provisions, a soft storey is defined as the storey in which the stiffness is less than $70 \%$ of the storey above or less than $80 \%$ of the combined stiffnesses of the three storeys above. It is the general practice in the multistoreyed buildings to accommodate parking facilities for the vehicles of the occupants of the building. As we know that the soft storey in a building structure causes stiffness irregularity in a structure, due to this the structure undergoes unequal storey drifts, formation of the plastic hinges and then finally resulting into the collapse of the structure. This research work purely interacts with the effect of the soft storeys in the analysis of RC framed structures as entitled above, and in this work the soft storeys positions has been provided at different levels as shown in the analytical modelling. All the models are analyzed by using the ETABS software. The seismic analysis performed consists of the Equivalent static analysis (ESA), response spectrum analysis (RSA), and the push over analysis (PA). The seismic base shear forces, storey drifts, and the displacements has been compared with the three analysis methods as listed above. With the aid of the push over analysis the values of the ductility and the response reduction factor have been obtained. Apart from these, the performance point parameters such as spectral acceleration(Sa), spectral displacement (Sd), Base shear $(V)$ and the roof displacement $(D)$ has been also illustrated in this work and a detailed information of several stages of the hinge formation $(A, B, I O, L S, C P, C, D, E)$ has also been illustrated..
\end{abstract}

Keywords: Soft Storey, Stiffness, Storey Drift, Storey Displacement, Earthquake, RC Frames.

\section{INTRODUCTION}

\subsection{General}

The basic fundamental earthquake resistant design concept is the strong columns-weak beams criteria, so as to ensure safety of the occupants, i,e during earthquake the beams yield before the columns get collapsed. From the past earthquake we see that many building structures that collapsed exhibited the opposite strong beam-weak columns behaviour i,e the columns failed before the beams yielded this is so because of the effects of the soft storeys provision. The behavior of the structure and degree of damages of the multistoreyed buildings depends on the capacity of structural members undergoing the process of deformations in elasticity during seismological ground motions. Taking into consideration the above points, the structural building frames must be evaluated, designed as per the inelastic deformations due to the effect of earthquakes, leaving the stresses induced by the equivalent static force as mentioned in various seismic codes The normal practice these days for the purpose of seismic forces resistant building design is dependable on fundamental principles of force based earthquake resistant building design. there were been various effort to consider $\&$ use the actual conceptual data of deformation based seismic design as well as evaluation in the earthquake resistant design of structural frame buildings. Using the studies of the inelastic earthquake response of building help us to improvize the codal provisions and also the guidelines regarding the reduction of the potential damages occurred during ground motion of buildings as well as it also helps in imparting economic design using reserved strength that which the building is experienced during inelastic deformations.

All the buildings designed based upon the now a day's existing codes of seismology imparts minimum safety of life of the citizens / occupants in a high magnitude earthquake.

\subsection{OBJECTIVES THE PRESENT STUDY}

\subsection{1 objectives}

- The top most priority is to perform lateral load analysis on the different structural building models based on the changes in the models as per the Indian codal provisions.

- Lateral load analysis with and without the provisions of a particular shape of a shear wall.

- Lateral load analysis of the models in particular with the soft storeys at various levels of the building models.

- To study the aspects with regard to the provision of core wall and its effects.

- To study seismicity behavior in various building models regarding the provision of with and without the masonary infill.

- To obtain the storey drifts \& displacements at each one of the storeys using equivalent static analysis method, 
response spectrum method and the famous non linear static method.

- Comparing the results from different methodologies.

- Accessing the performance point of the building thus coming to the conclusion with regard to the performance levels of the structure.

\subsubsection{Scope of the Study}

The purpose of this hypothetical study is to evaluate the seismic properties and characteristics for multistoreyed residential building structures. The main aspect of this analysis is to obtain the sustainability of the building regarding the performance of the buildings by using the aid of capacity and the demand of the structure for a designed strong motion earthquake characteristics using the equivalent static method, response spectrum method, and push over methods of analysis.

\section{METHODS OF SEISMIC ANALYSIS}

\subsection{General}

The purpose of the carrying out the process of seismic analysis is to find actually the several parameters which purely includes the force, the deformation, capacity of each of the components in the building structure. These analysis methodologies are listed in a hierarchical order as follows:

- Linear static analysis. (ESA)

- Linear dynamic analysis. (RSA)

- Non linear static analysis. (push over)

\subsubsection{Linear Static Analysis}

\section{(Equivalent Static Method)}

This is one of the simple most analysis procedures which makes ease for the structural designer to perform and carry out the design process. This analytical method is also prescribed in almost all the codal formats used for seismological analysis and is used mostly for the building which has some regular parameters of components for the purpose of design. This method is also popular by the name lateral forces method as the effects in this method of seismic motion are purely assumed to be the similar one as that which becomes as a result from the static transverse loads.

The different codal provisions gives their own methods to obtain and to distribute the static forces so that to obtain the effects of seismic ground motion on the structural frames. Generally the expression is initially defined to set a prescribed value of the minimal lateral seismic force, which is also named as the base shear force. The single basic general requirement for the building structure with respect to the application of this methodology is purely that the natural vibration period of the building structure must be limited to a maximal values, which certainly results to a minimal values of frequency or the stiffness. This is because of fact that the often response is primarily controlled by it's the first modes of vibrations. Resulting therefore in minimal values of frequency the contribution of the higher modes can be generally neglected.

\subsubsection{Linear Dynamic Analysis (Response Spectrum Analysis)}

The linear dynamic method of analysis has been proved to be the efficient ever design methods and almost mostly used and suggested by the structural designers for the purpose of analysis and design of the RC framed structure and their respective components.

When we carry out the dynamic analysis, the inelastic response is empirically purely reviewed, As the non linear behavioural properties of the buildings which purely govern the designing under the strong ground motion. Due to these reasons the designers suggests and they too prefer the simplex methodology to carry out the analysis with the help of the elastic dynamic analysis methods. The consideration of the modal contributions of each modes is the very important parameter in case of the multistoreyed buildings. A unique deformation possess at each single modes. The several important factors of the building structures are purely depends on the contributions from these vibration modes. The modal contributions resulting from the higher modes is smaller for the seismic response of a short to medium rised buildings because of the influencing property of the fundamental mode is very larger that is in the range of about $70-90 \%$.

Here in this method it is mostly important to consider the vibrations at the initial stages so that we get the results in a almost nearer exactly conditions.

\subsubsection{Non-Linear Static Analysis}

\section{(Pushover Analysis)}

The non linear statically analysis is static method technique in a non linear methodology. In this method when the loadings are imposed or acted in a vertical manner and also the laterally application of loadings are both applied in a increments which gives the forces resulting from the seismic motions of the ground that is the earthquake.

In this method after the analysis is carried out we will certainly get from the results a graph of base shear V/S displacements which gives the bending failures. This methodology of analysis is donned until we get failure points. This failure point gives a pathway to obtain the loads which are acting purely on the building during the time of collapse.

There will be a decrease in the stiffness followed after the loads are applied in the equal quantities increment and also due to this the hinges will also be eventually developed. The pushover methods of analysis are of the two types as illustrated below:

1. Force controlled push over analysis.

2. Displacement controlled push over analysis. 


\section{ANALYTICAL MODELLING}

\section{1description of Models}

Model 1: The model-1 is a bare frame model

Model 2: The building has full infill masonry all over the model.

Model 3: The building consists of soft storeys in plinth as well as in ground storey and the remaining storeys consist of masonry infill.

Model 4: The building has first and second storeys as soft storeys and all other storeys are masonry infilled including plinth.

Model 5: The building model has soft storey's from plinth till $3^{\text {rd }}$ storey and remaining portion of the building model is masonry infilled.

Model 6: The building has first storey, second storey, third storey, and top two storeys as soft storeys and all other remaining storeys as masonry infill.

Model 7: The building has top two storeys as soft storeys and all other remaining storeys as masonry infill.

Model 8: In this building model all storey's is provided with masonry infill except for storey 1, 2, 3 where L shaped shear wall is provided only at corners.

Model 9: In this building model storey 1,2,3 is provided as soft storeys and top 2 storey's are glazed (glass load is applied from IS 875), all other remaining storeys as masonry infill but with the addition of a central core wall.

Model 10: The building has full brick infill masonry with the inclusion of square shaped shear wall in the corner four grids.

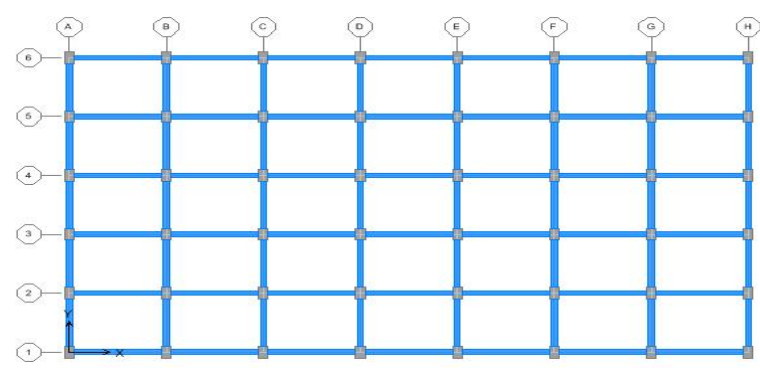

Fig: 1 common plan for all models

(5m spacing in $X$ direction and $4 \mathrm{~m}$ spacing in $Y$ direction)

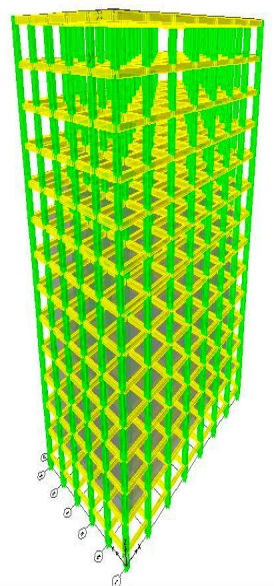

Fig:2 model-1 (bare frame)

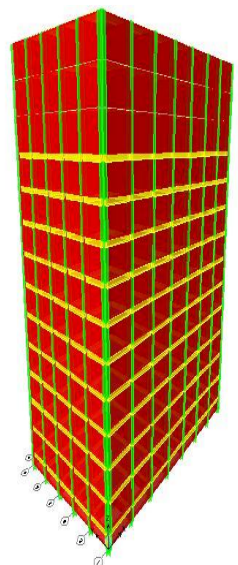

Fig:3 model-2

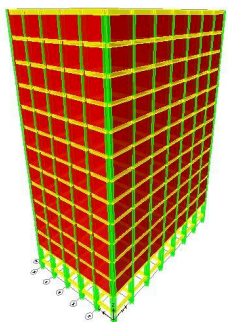

Fig:4 model-3

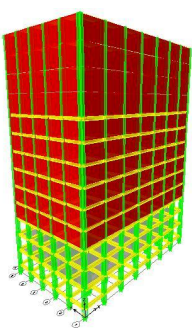

Fig:6 model-5

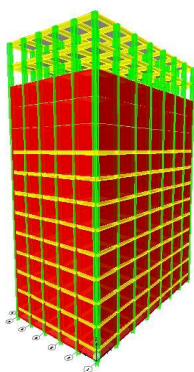

Fig:8 model-7

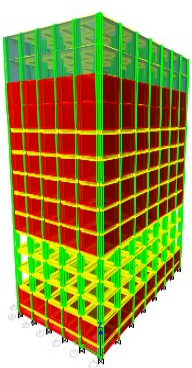

Fig:10 model-9

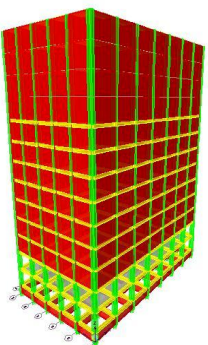

Fig:5 model-4

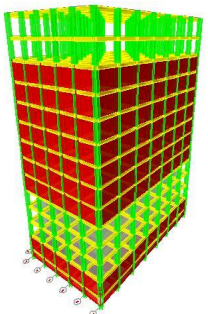

Fig:7 model-6

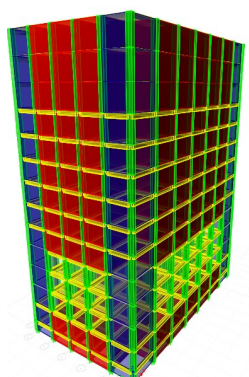

Fig:9 model-8

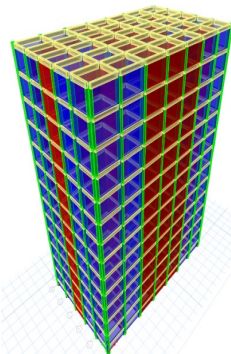

Fig:11 model-10

\subsection{Design Data}

\subsubsection{General}

Occupancy $=$ Residential

Height of each storey $=3.5 \mathrm{~m}$

Depth of foundation $=2.0 \mathrm{~m}$

\subsubsection{Loads}

Live load $=3.0 \mathrm{KN} / \mathrm{m}^{2}$ Floor finishes $=1.0 \mathrm{KN} / \mathrm{m}^{2}$ Wall load $=12.627 \mathrm{KN} / \mathrm{m}$

\subsubsection{Seismic Data:}

Zone factor (table 2 of IS: 1893-2002) $=0.24$ (Zone IV) Importance factor (table 6 IS : 1893-2002) $=1.0$ 
Response reduction factor (table 7 IS: 1893-2002) $=5$ (SMRF)

Soil type (figure 2 of IS 1893-2002)=Type II (Medium soil)

\subsubsection{Member Properties:}

Thickness of RC slab $=0.150 \mathrm{~m}$

Column size $=(0.3 \times 0.8) \mathrm{m}$

Beam size $=(0.3 \times 0.6) \mathrm{m}$

Thicknesses of brick masonry wall $=0.230 \mathrm{~m}$

Thicknesses of RC shear wall $=0.230 \mathrm{~m}$

\subsection{Assumptions}

1. The material is elastic linearly.

2. The material is homogenous and isotropic.

2. The supports to the columns are taken as fixed at the foundation.

3. The tensile strength of concrete is ignored in sections subjected to bending.

4. Pushover hinges are assigned to all the member ends. In case of Columns PMM hinges are provided at ends, but as in case of beams M3 hinges are provided at both ends.

5. The analysis of the superstructure is carried out independent from the foundation as well as the soil medium 6. Due to rigidity of structure the floor acts as diaphragm.

\section{ANALYTICAL \\ DISCUSSIONS}

RESULTS

AND

The results obtained are of various parameters such as fundamental natural time period, storey drifts, storey displacements, and the design seismic base shear etc. where as the pushover analysis parameters such as the performance point parameters such as spectral acceleration( $\mathrm{Sa})$, spectral displacement $(\mathrm{Sd})$, Base shear(V) and the roof displacement(D) are also obtained.

\subsection{Fundamental Natural Time Period}

Chart no-1

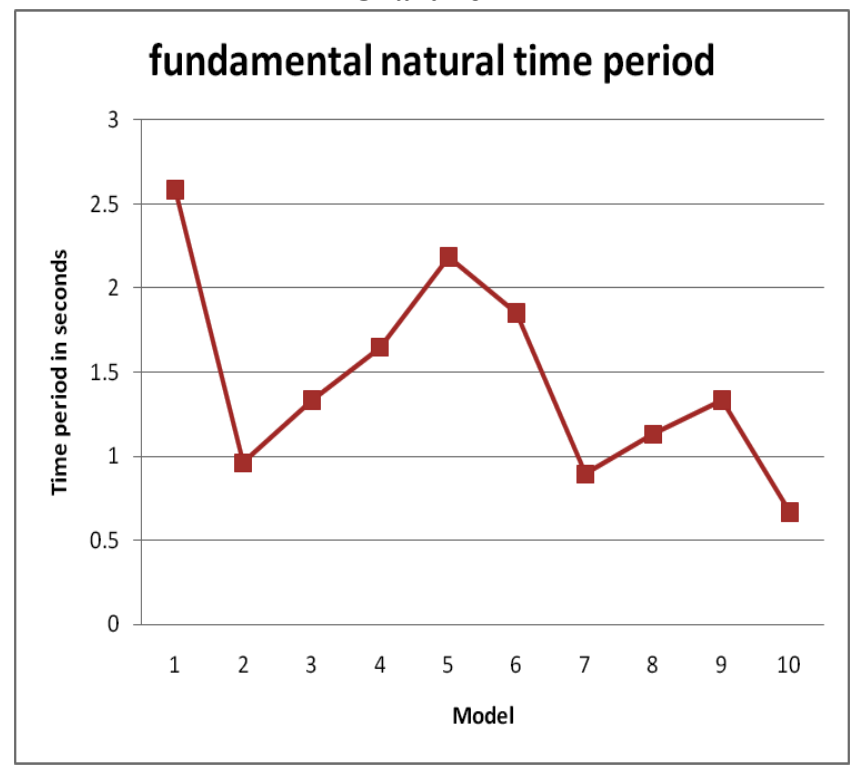

Table-1 Fundamental natural time period for different building models

\begin{tabular}{|l|l|}
\hline Model No & T in sec \\
\hline 1 & 2.5852 \\
\hline 2 & 0.958 \\
\hline 3 & 1.3319 \\
\hline 4 & 1.6454 \\
\hline 5 & 2.1828 \\
\hline 6 & 1.8495 \\
\hline 7 & 0.8920 \\
\hline 8 & 1.1299 \\
\hline 9 & 1.3302 \\
\hline 10 & 0.6641 \\
\hline
\end{tabular}

While comparing all the models the model no 10 has a smallest value as compared to all other models, where as model no 01 has the highest value. And also model no 2,3,4,7,8,\&9 has the small values and model no 5,6 has higher values.

Therefore we can easily come to conclusion that the provision of infill and also the shear wall reduces the fundamental natural period of the building.

\subsection{Design Seismic Base Shear:}

Table-2 Design seismic base shear for all models in both directions

\begin{tabular}{|l|l|l|}
\hline Model No & $\begin{array}{l}\text { Design seismic base } \\
\text { shear in KN } \\
\text { (Longitudinal } \\
\text { direction) }\end{array}$ & $\begin{array}{l}\text { Design seismic base } \\
\text { shear in KN } \\
\text { (Transverse } \\
\text { direction) }\end{array}$ \\
\hline 1 & 2890.87 & 3332.82 \\
\hline 2 & 16468.12 & 13193.71 \\
\hline 3 & 9114.98 & 9742.32 \\
\hline 4 & 7209.29 & 8071.99 \\
\hline 5 & 5205.38 & 6037.07 \\
\hline 6 & 5782.83 & 6651.20 \\
\hline 7 & 16244.94 & 13298.66 \\
\hline 8 & 12129.55 & 10366.44 \\
\hline 9 & 10131.71 & 8967.72 \\
\hline 10 & 24159.28 & 19789.04 \\
\hline
\end{tabular}

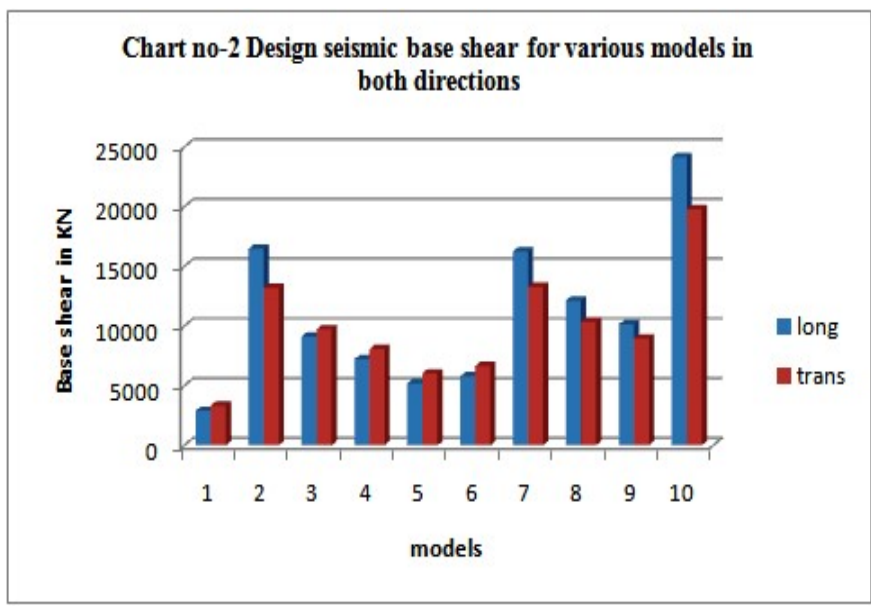


From above chart no- 2 we see that the base shear values in both the longitudinal as well as transverse direction are at its peak (highest) in the model no-10. Also we see that the model no-2 and the model no-7 has significant values of base shear as in comparison to the other models. Here we found that the bare frame model i,e model no-1has the lowest values of base shear in both longitudinal and transverse direction. In the model no-5 \& 6 the base shear values in both directions have almost the nearer values.

\subsection{Displacement and Base Shear At Yield Point}

Table-3 displacement and base shear at yield point along $\mathrm{X}$ direction

\begin{tabular}{|l|l|l|}
\hline Model No & $\begin{array}{l}\text { Base shear at } \\
\text { first hinge(KN) }\end{array}$ & $\begin{array}{l}\text { Displacement at } \\
\text { first hinge(mm) }\end{array}$ \\
\hline 1 & 1308.51 & 0.0177 \\
\hline 2 & 59553.58 & 0.0458 \\
\hline 3 & 6282.77 & 0.0104 \\
\hline 4 & 3088.06 & 0.0074 \\
\hline 5 & 2458.51 & 0.0102 \\
\hline 6 & 2604.16 & 0.0100 \\
\hline 7 & 18000.75 & 0.0181 \\
\hline 8 & 10237.99 & 0.0108 \\
\hline 9 & 5222.78 & 0.0077 \\
\hline 10 & 60130.55 & 0.0238 \\
\hline
\end{tabular}

Table-4displacement and base shear at yield point along $\mathrm{Y}$ direction

\begin{tabular}{|l|l|l|}
\hline Model No & $\begin{array}{l}\text { Base shear at } \\
\text { first hinge(KN) }\end{array}$ & $\begin{array}{l}\text { Displacement at } \\
\text { first hinge }(\mathrm{mm})\end{array}$ \\
\hline 1 & 2801.55 & 0.0295 \\
\hline 2 & 41387.53 & 0.0533 \\
\hline 3 & 10764.96 & 0.0199 \\
\hline 4 & 6024.88 & 0.0142 \\
\hline 5 & 4315.73 & 0.0154 \\
\hline 6 & 4806.91 & 0.0156 \\
\hline 7 & 32231.66 & 0.0448 \\
\hline 8 & 10218.14 & 0.0159 \\
\hline 9 & 7317.35 & 0.0151 \\
\hline 10 & 66071.25 & 0.0407 \\
\hline
\end{tabular}

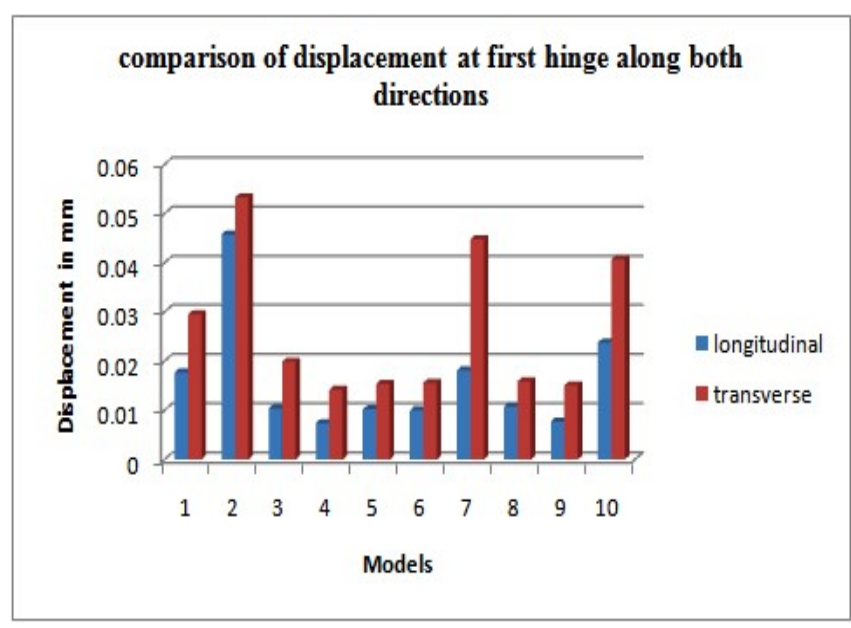

Chart -3

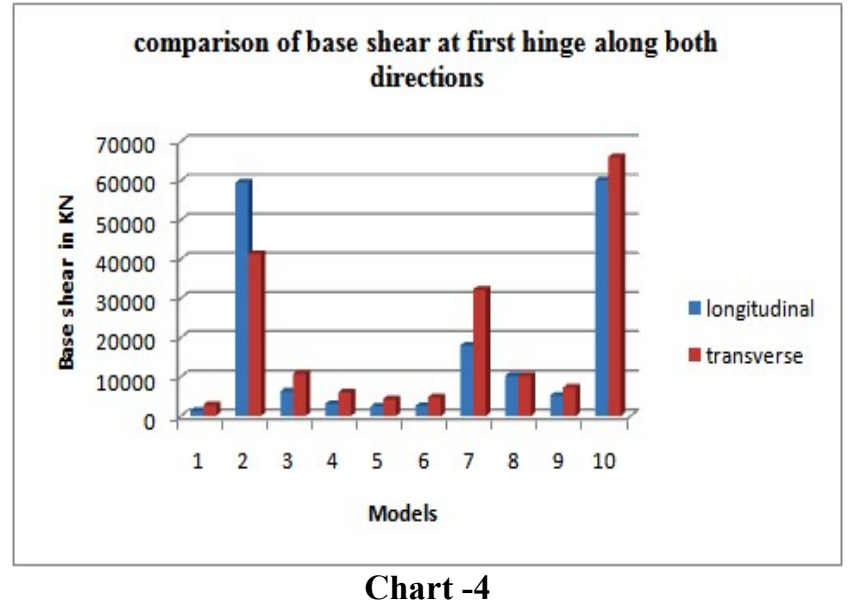

As seeing the table $3 \& 4$ and chart $3 \& 4$ we see that the displacement at first hinge is at its peak for model no- 2 in both directions and then the model-7 \& 10 has the significant values of displacement in transverse direction, regarding the base shear at first hinge the model-10 has the highest values of base shear in boyh directions and then model-2 has the significant values. The above result shows that due to shear wall increases base shear and further which reduces the displacement of the building.

\subsection{Story Drifts}

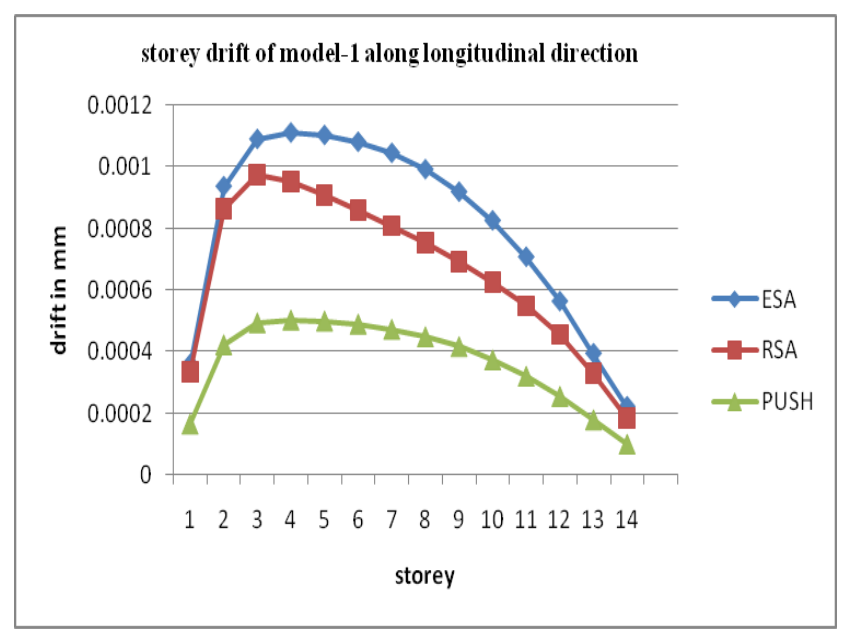

Chart -5

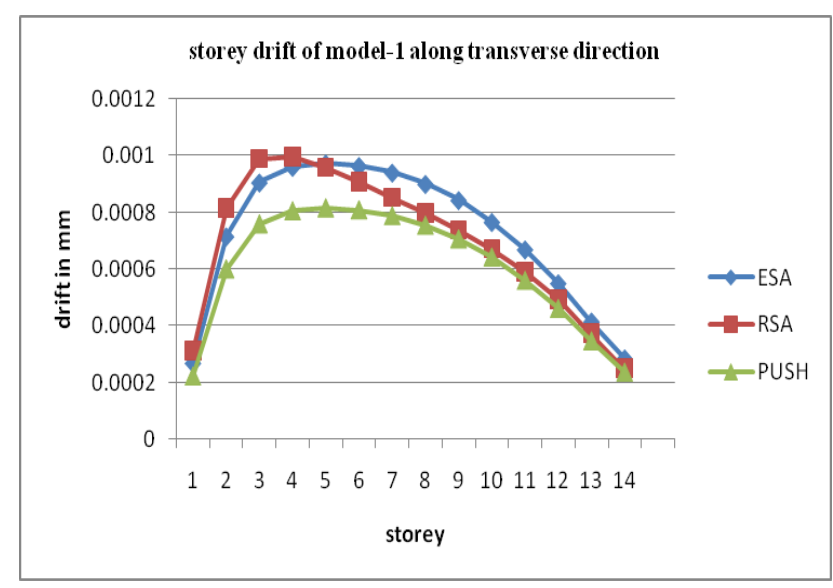

Chart -6 


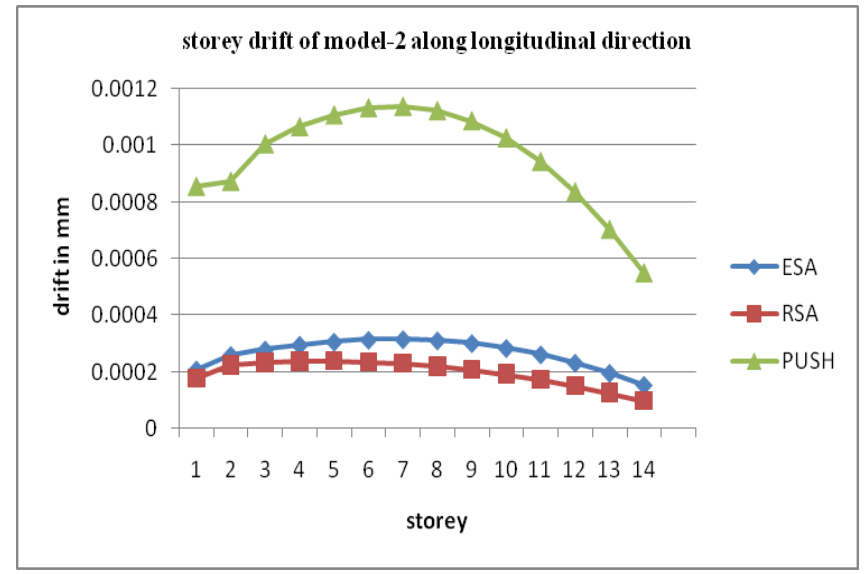

\section{Chart -7}

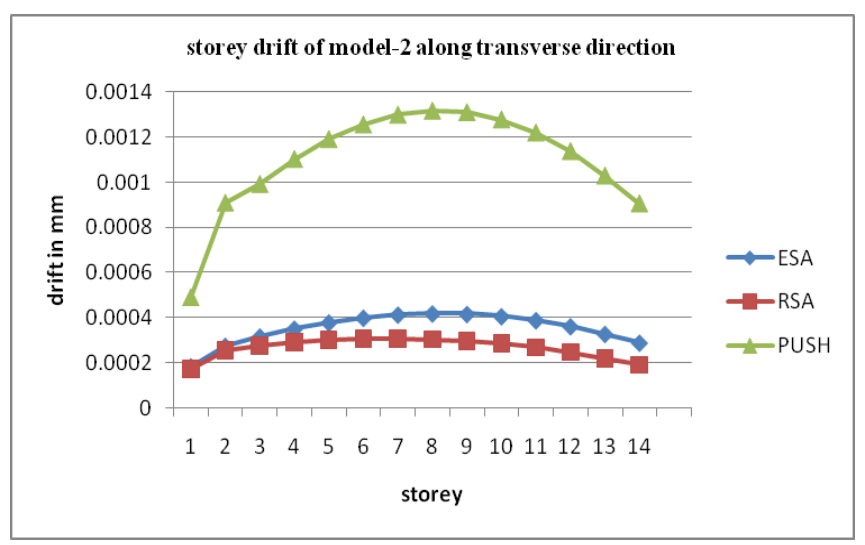

Chart -8

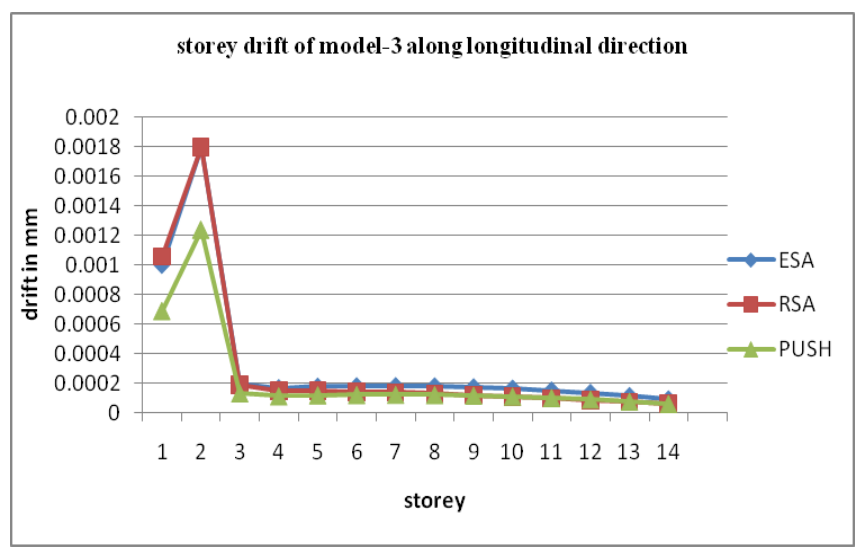

Chart -9

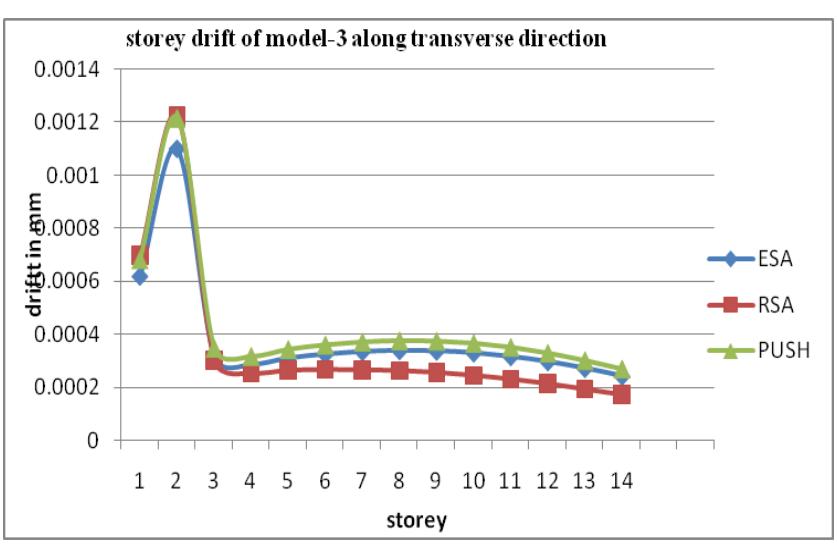

Chart -10

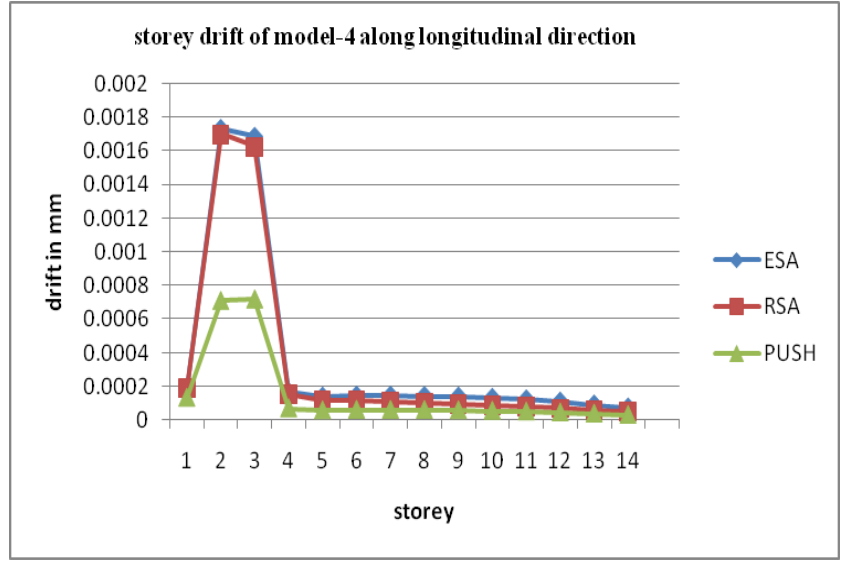

Chart -11

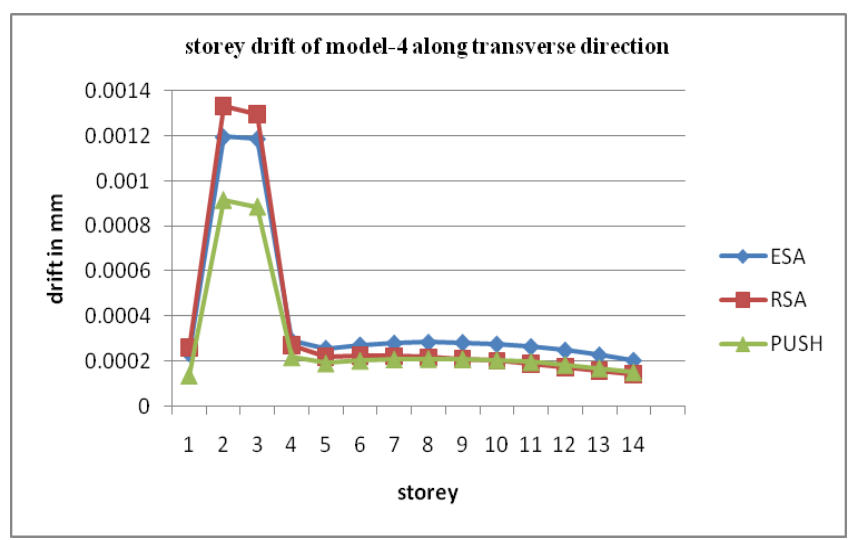

Chart -12

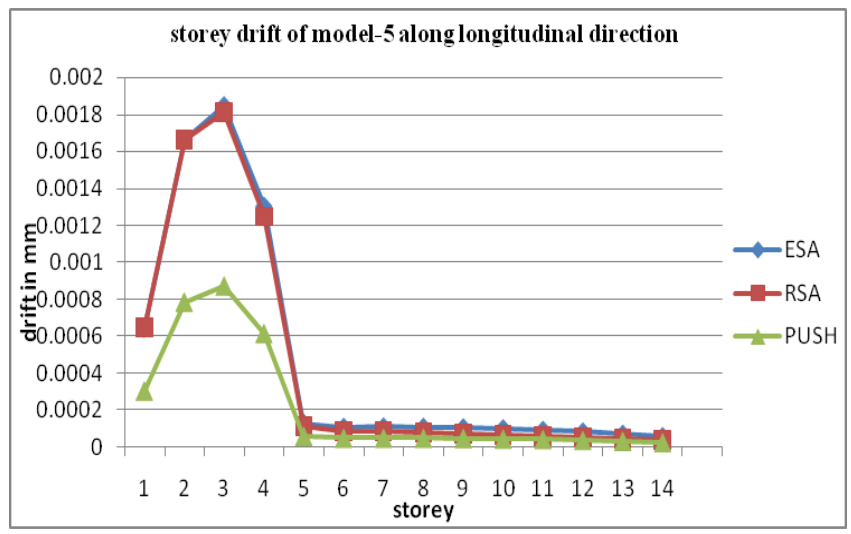

Chart 13

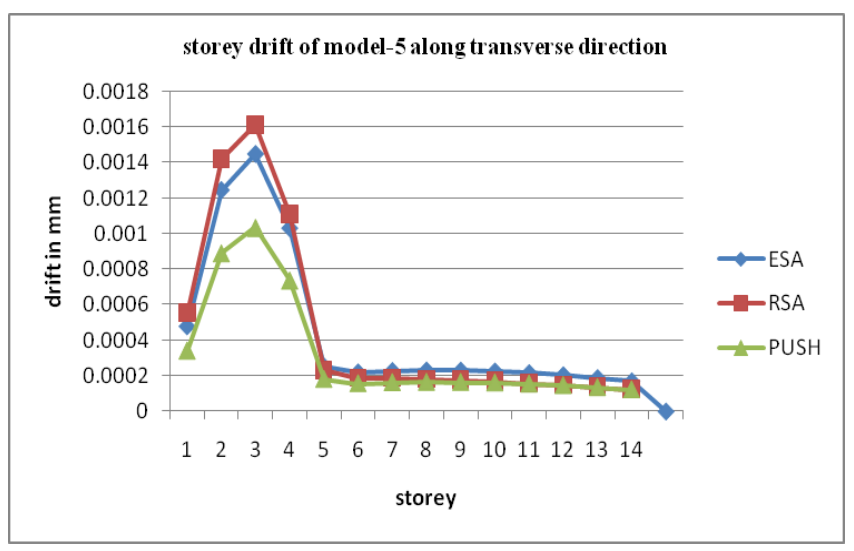

Chart -14 


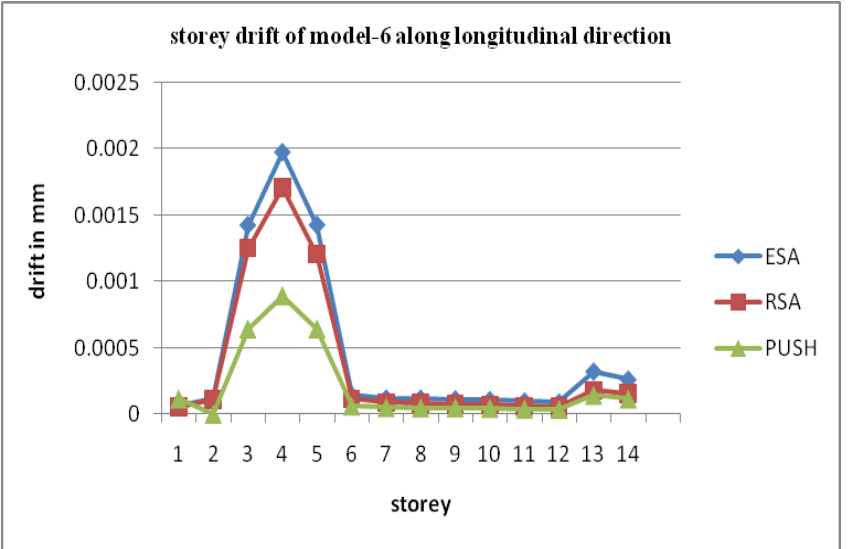

Chart -15

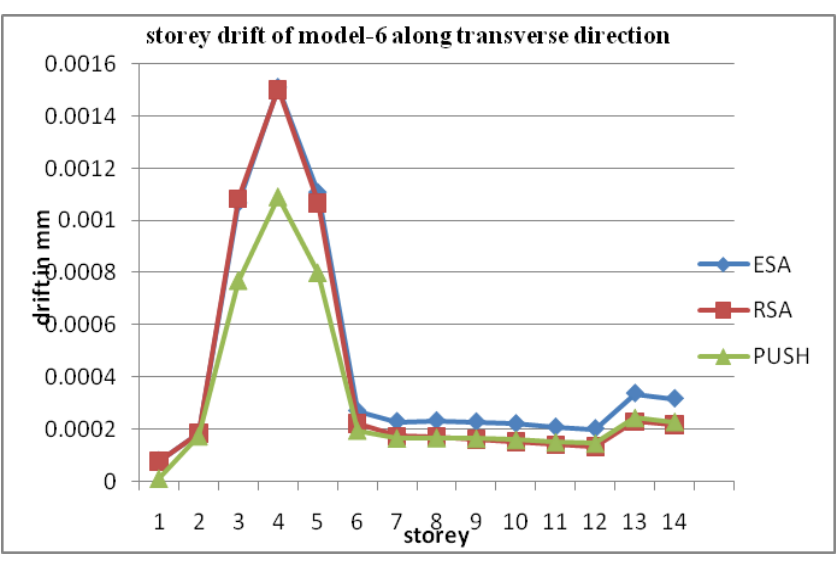

Chart -16

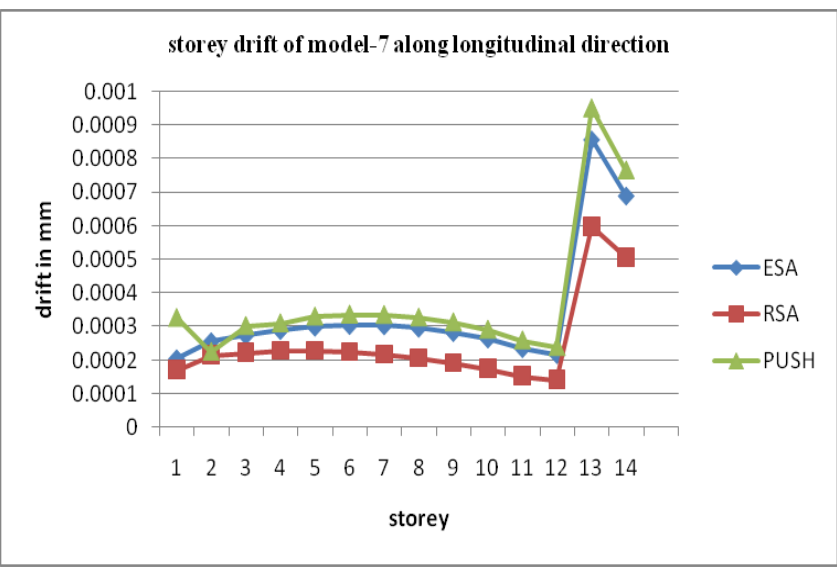

Chart -17

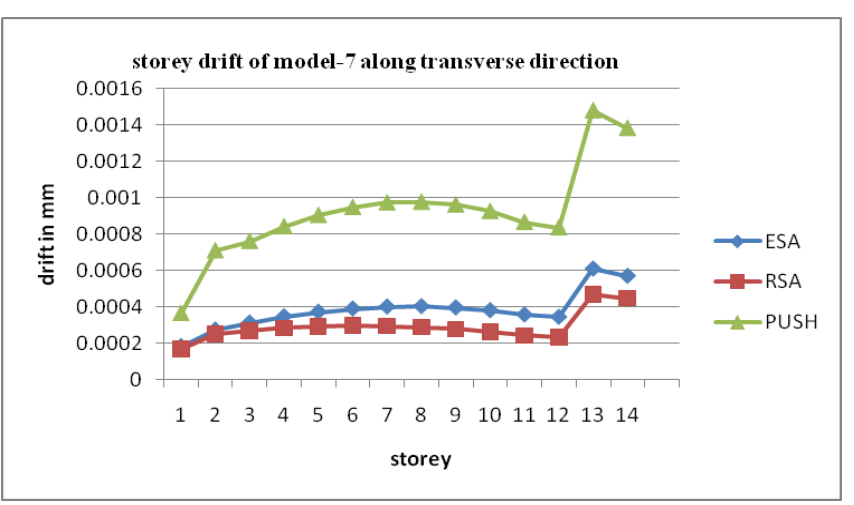

Chart -18

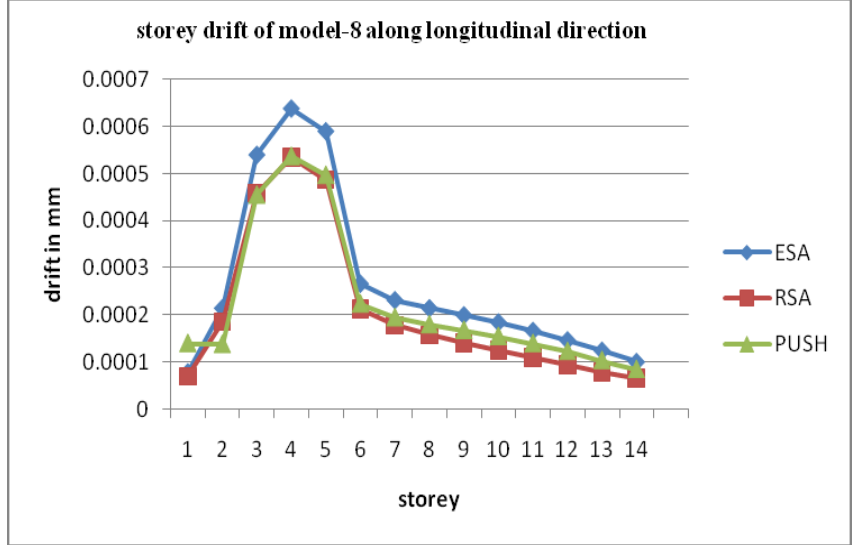

Chart -19

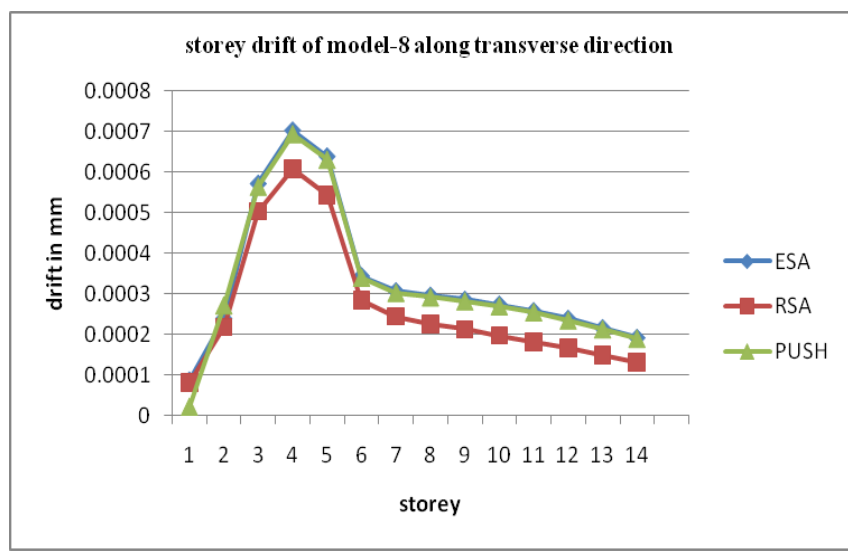

Chart -20

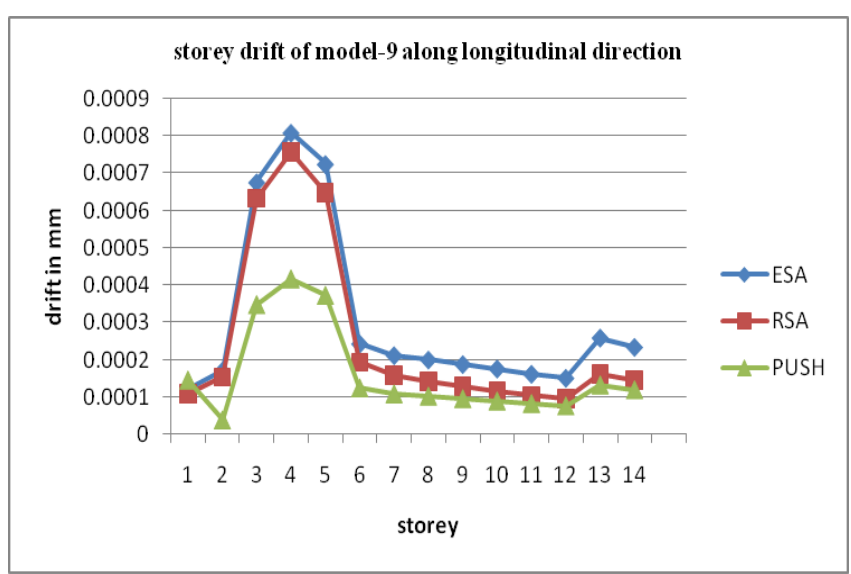

Chart -21

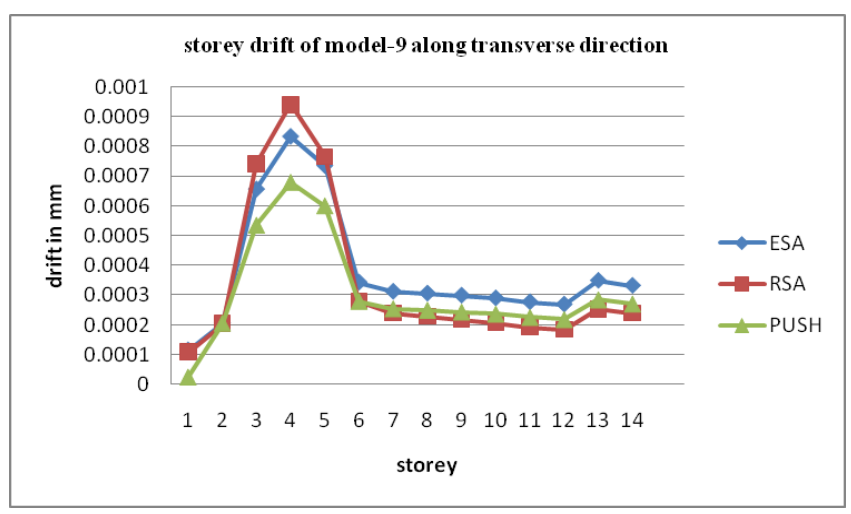

Chart -22 


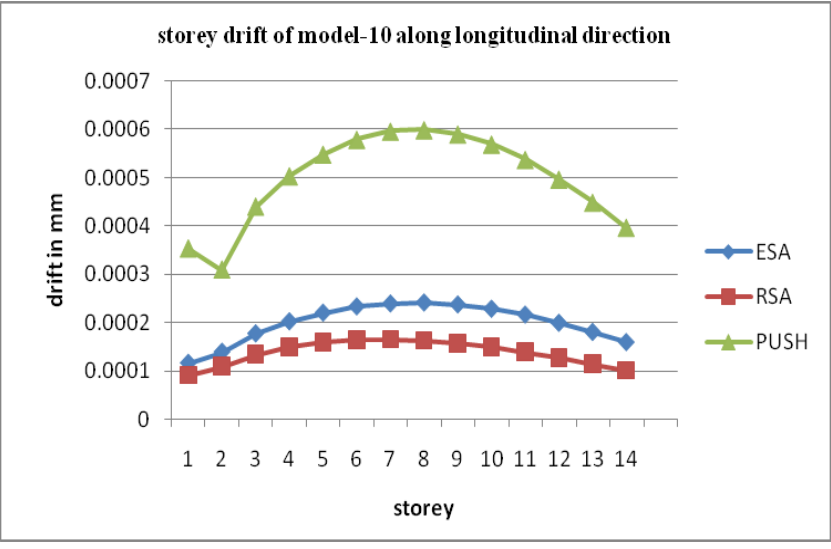

Chart -23

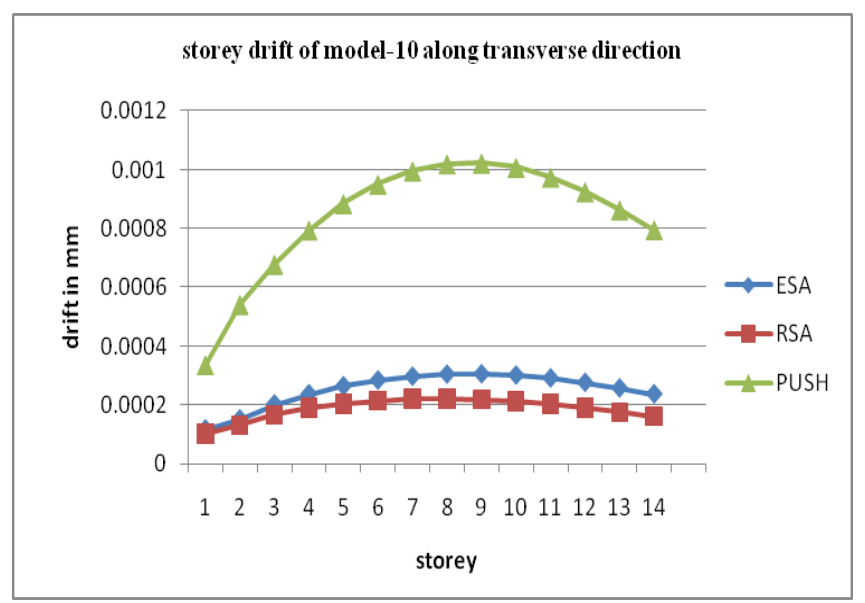

Chart -24

From the chart $5 \& 6$, it can be seen that the bare frame model (model 1) yields higher drift values as compared to other models .The drift values gradually increases from storey level 2 to storey level 7 then starts decreasing from storey 7 in the both the directions as shown in the chart 5.0\&6.0. Also the storey drift in both the directions satisfy the permissible limit i.e. $0.004 * \mathrm{~h}=0.004 * 3.5=0.014 \mathrm{~m}$ $=14 \mathrm{~mm}$.

From the chart 7 to 24 , it can be seen that the storey drift has higher values for models with soft storey as compared to that for models with full infill due to the fact that the infill presence increases the stiffness which results in decrease of storey drift. It is noticed that the storey drift curve of pushover analysis lies above that of equivalent static and response spectrum analysis in models with infill i.e. models 2,7 and 10 whereas for models $3,4,56$ and $9^{\text {th }}$ model the storey drift curve of pushover lies below that of ESA and RSA because of the soft storey. We also see, the model 8 and model 10 yields in which shear wall is present yields comparatively lesser storey drifts than models without shear walls i.e. models $2,3,4,5,6,7,9$ Hence it can be concluded that providing shear wall at the core, and also at the corners in $\mathrm{x} \& \mathrm{y}$ directions will significantly reduces the drifts in the storeys.

\subsection{Displacements}

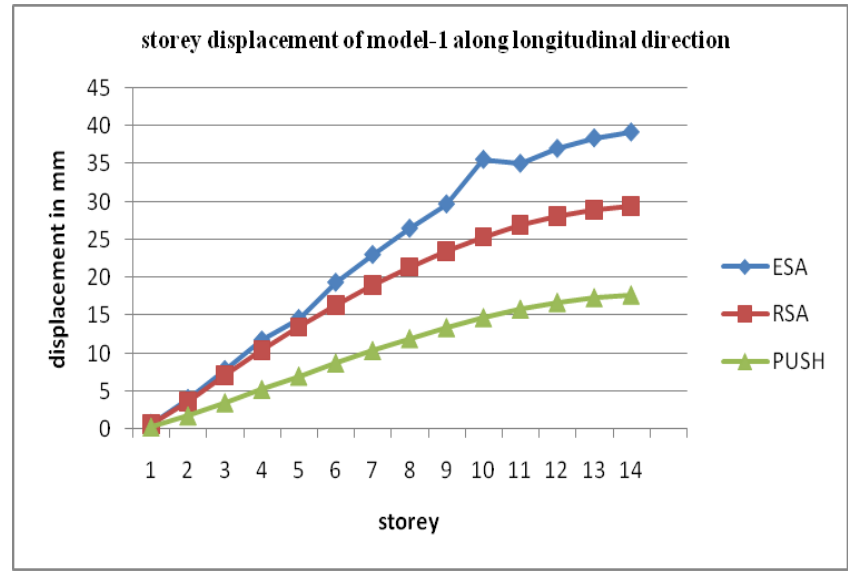

Chart -25

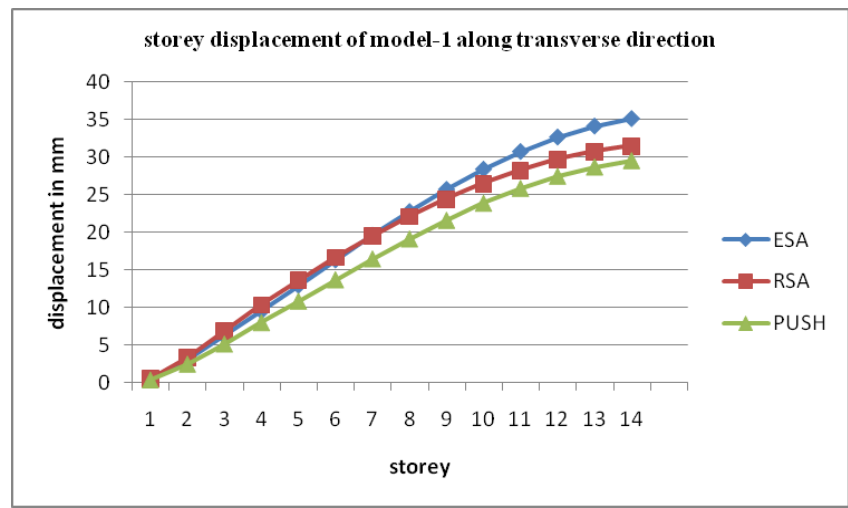

Chart -26

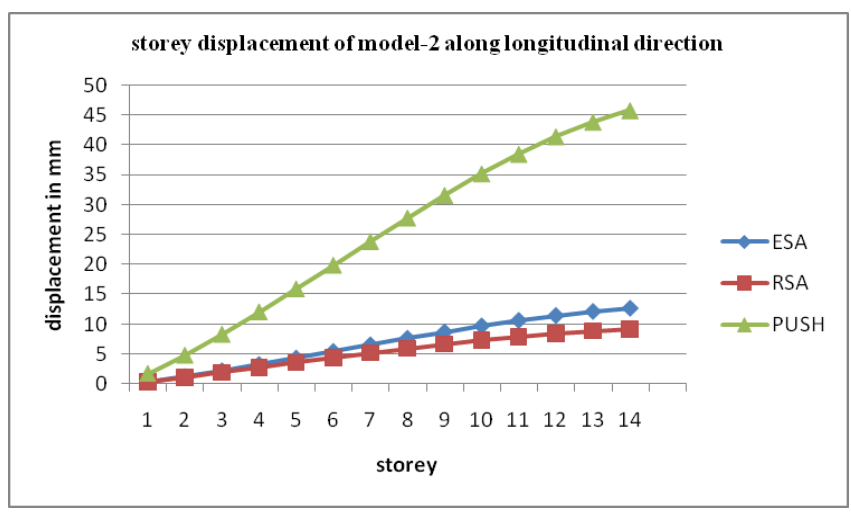

Chart -27

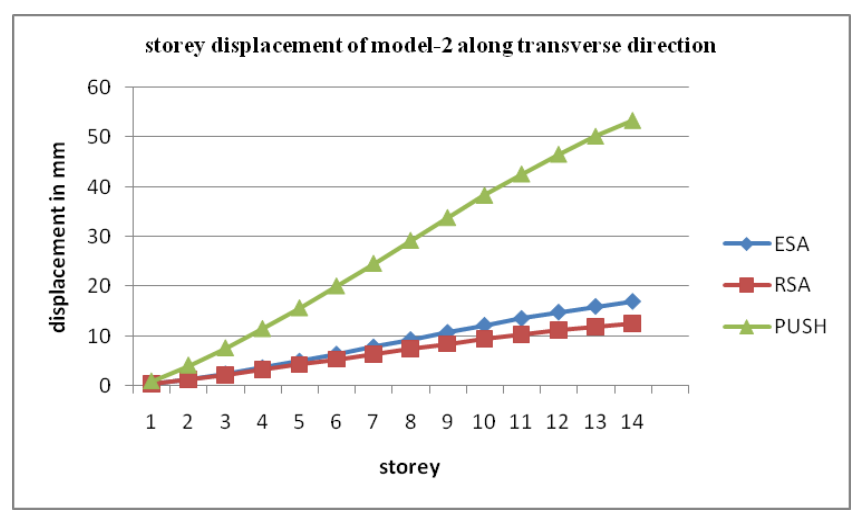

Chart -28 


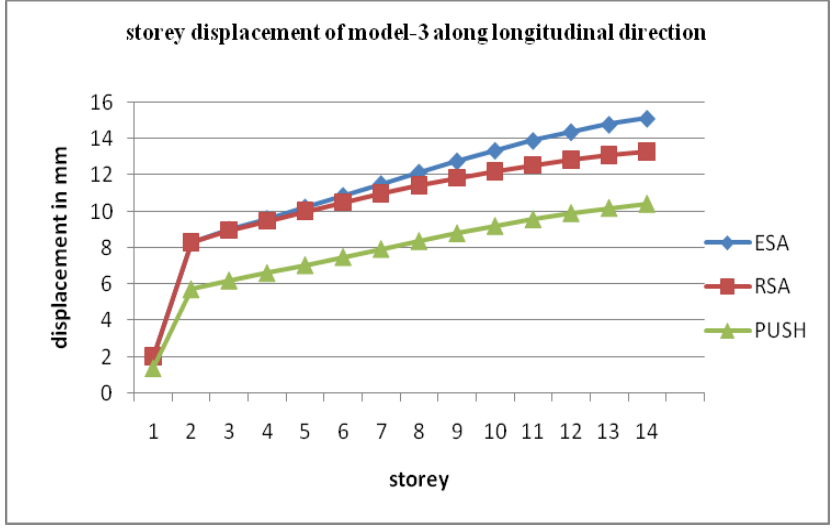

Chart -29

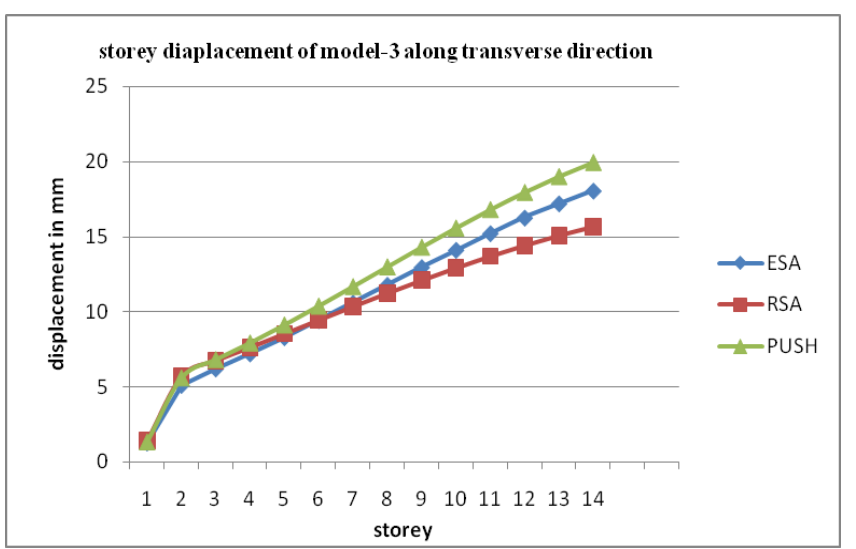

Chart -30

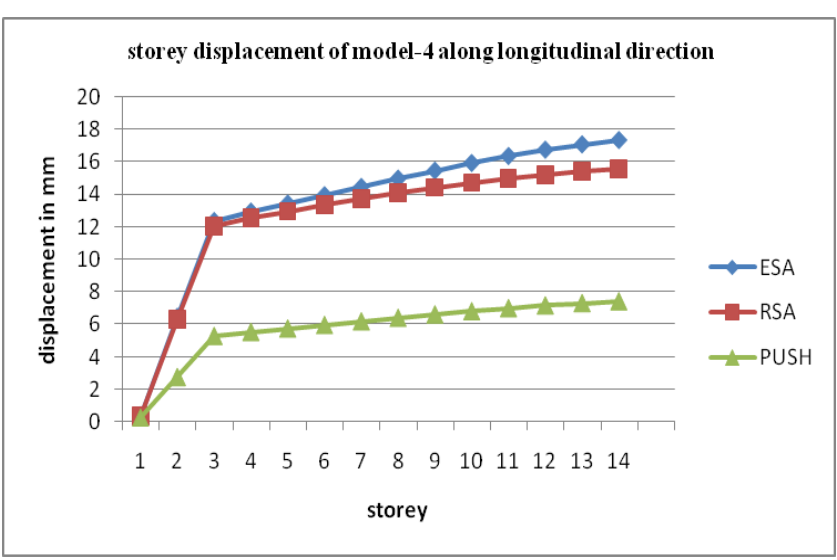

Chart -31

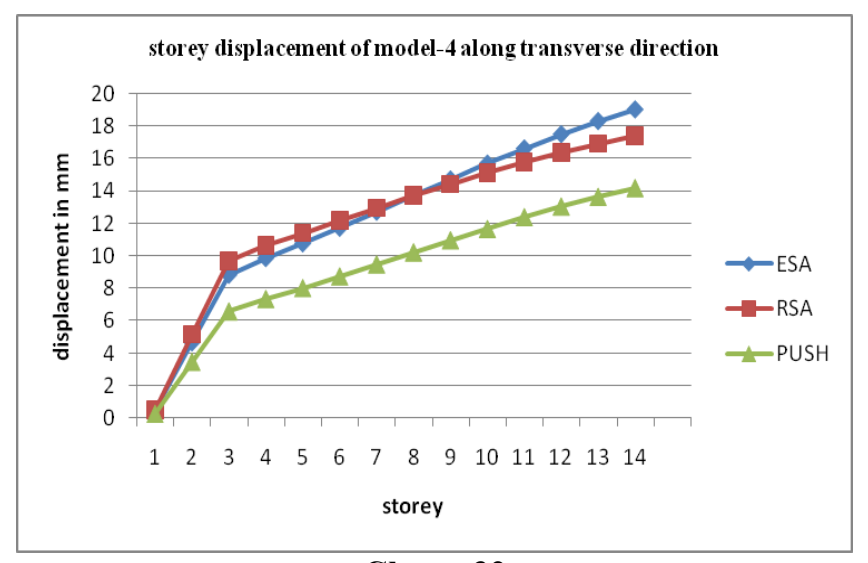

Chart -32

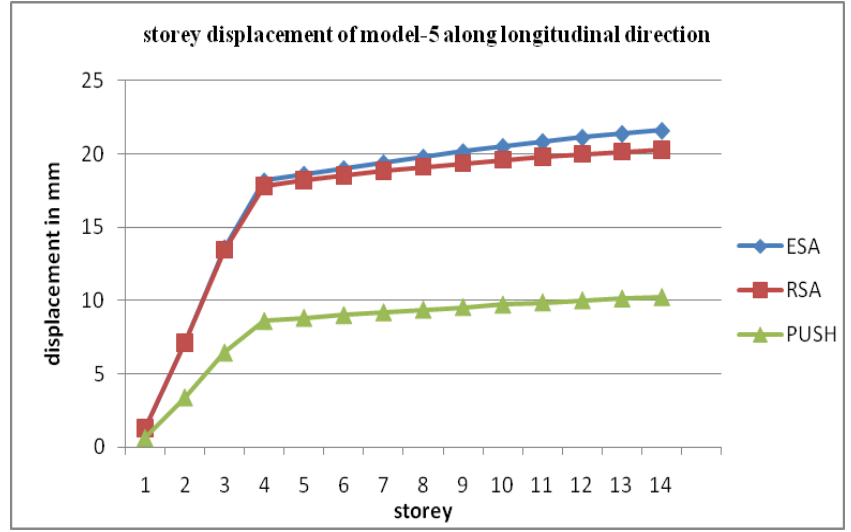

Chart -33

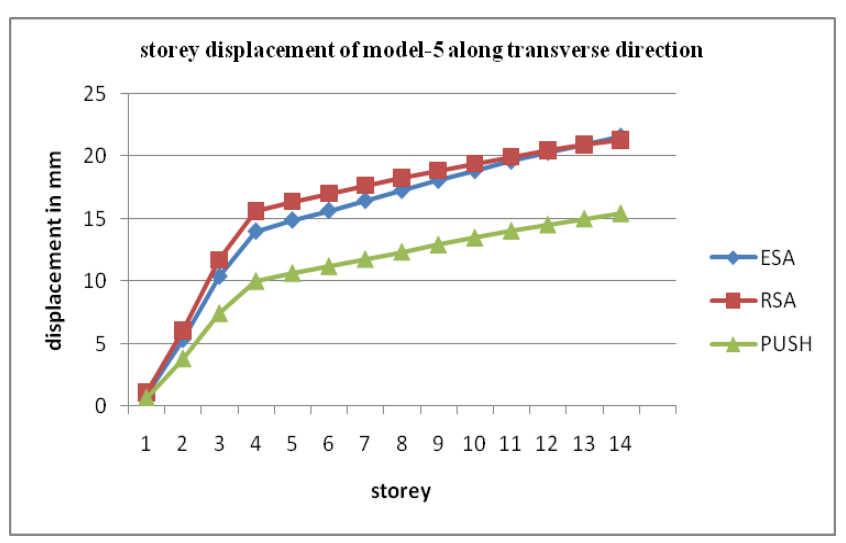

Chart -34

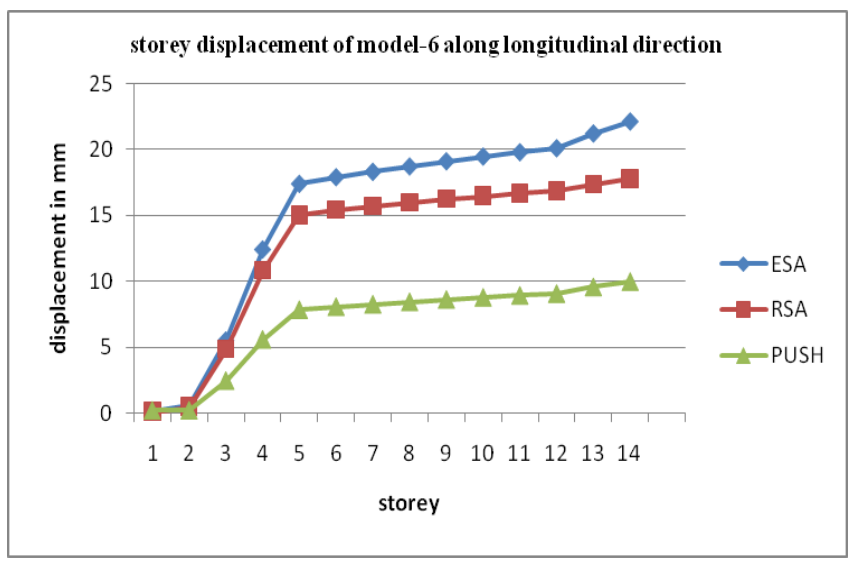

Chart -35

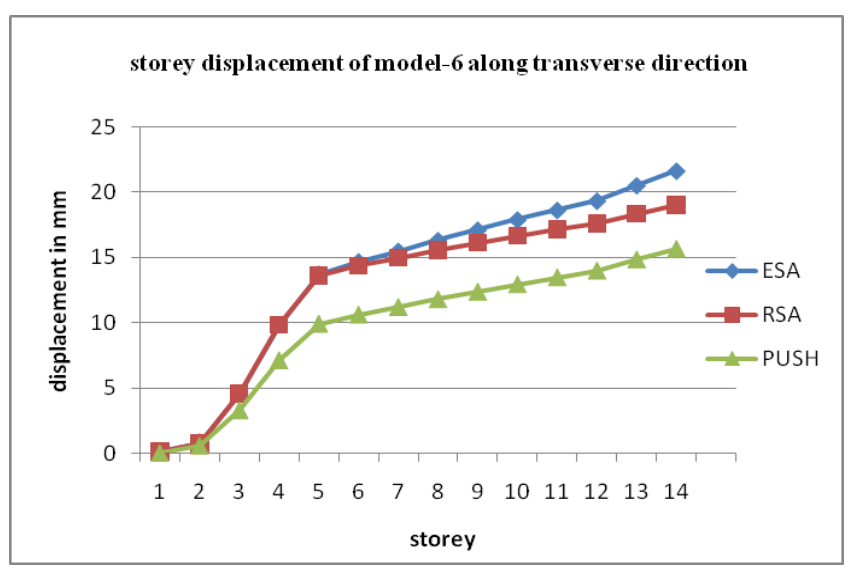

Chart $\mathbf{- 3 6}$ 


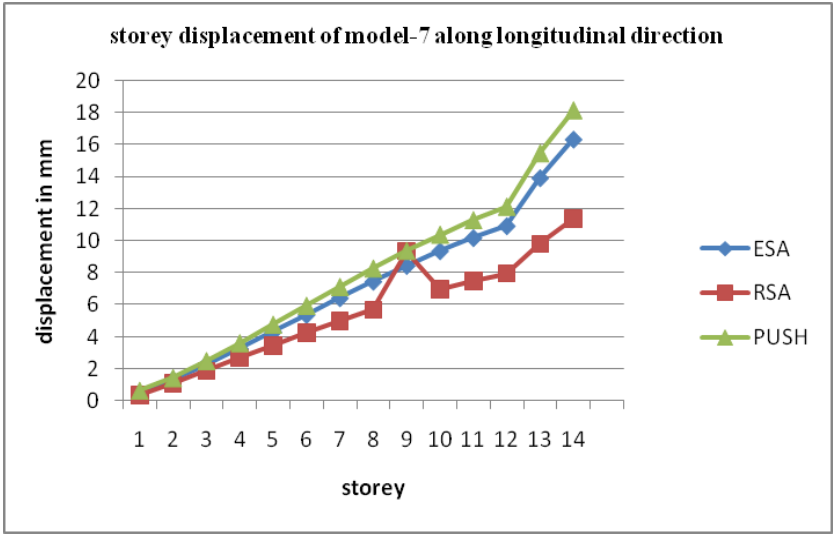

Chart -37

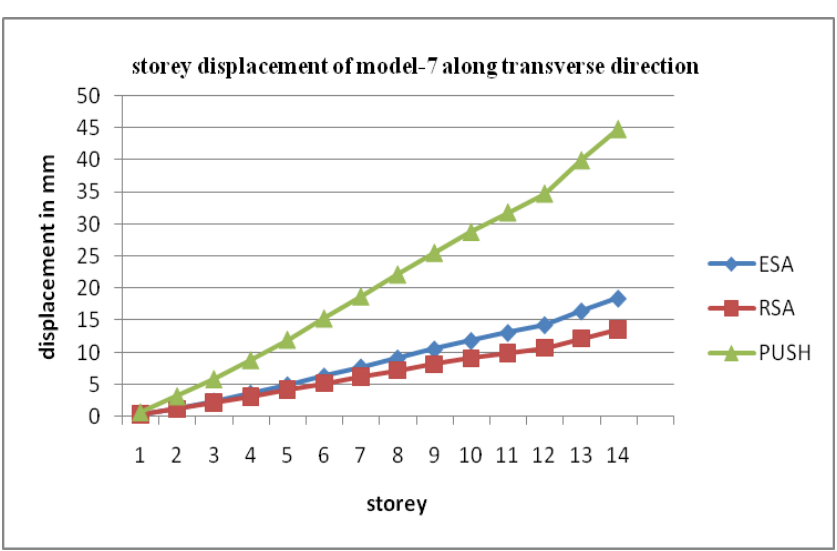

\section{Chart -38}

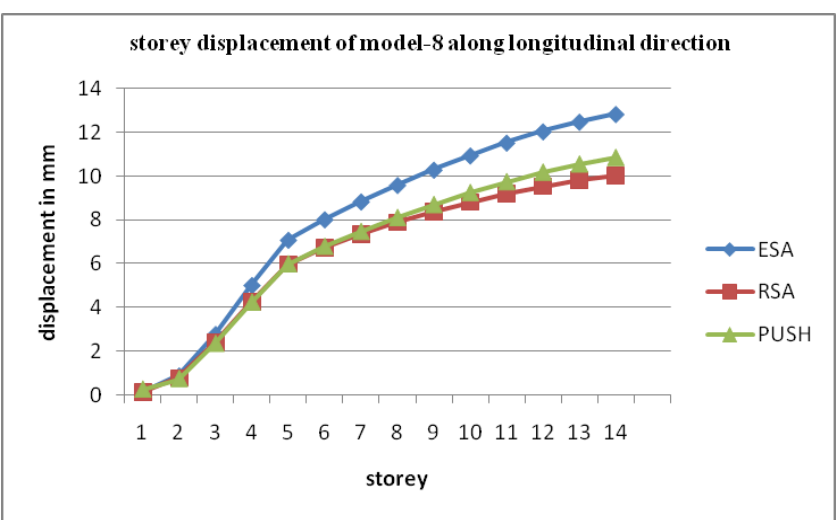

Chart -39

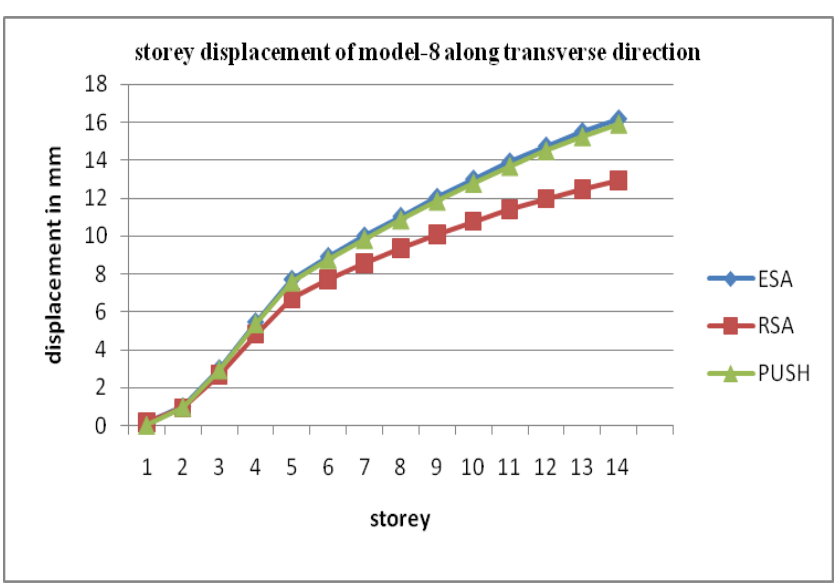

Chart -40

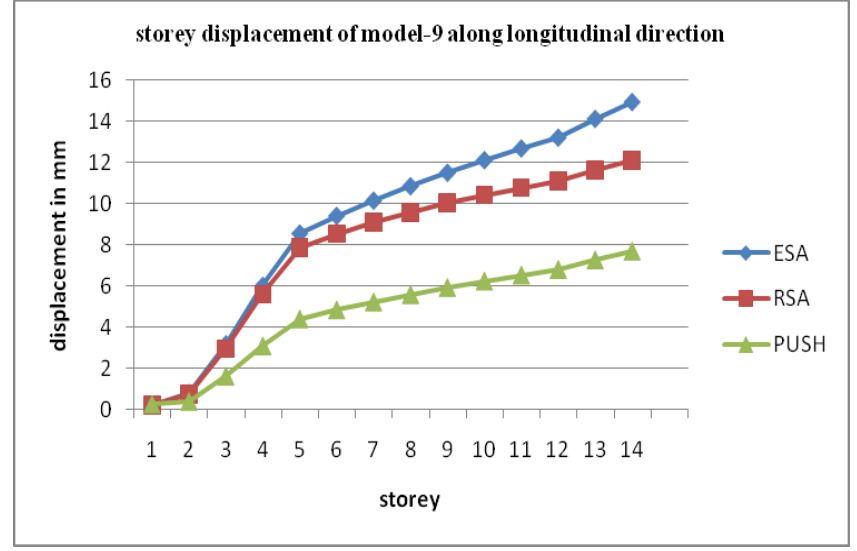

Chart -41

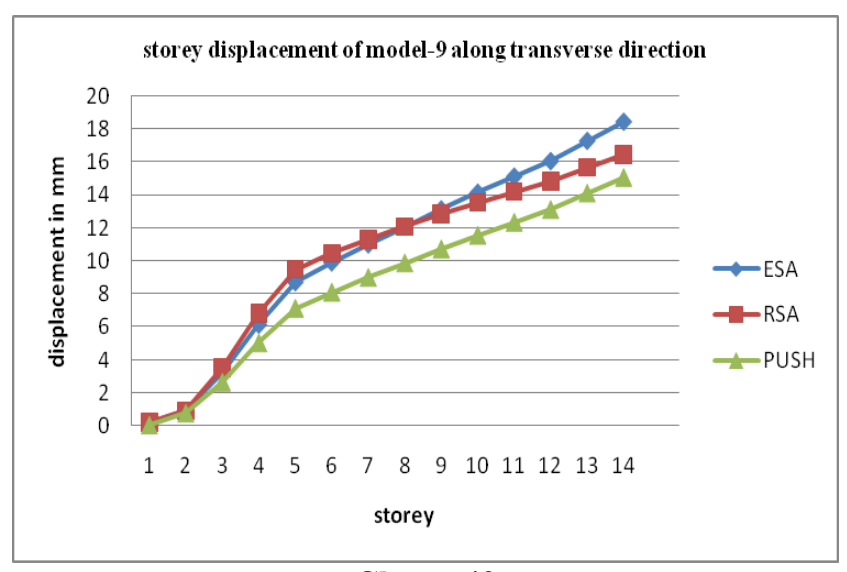

Chart $\mathbf{- 4 2}$

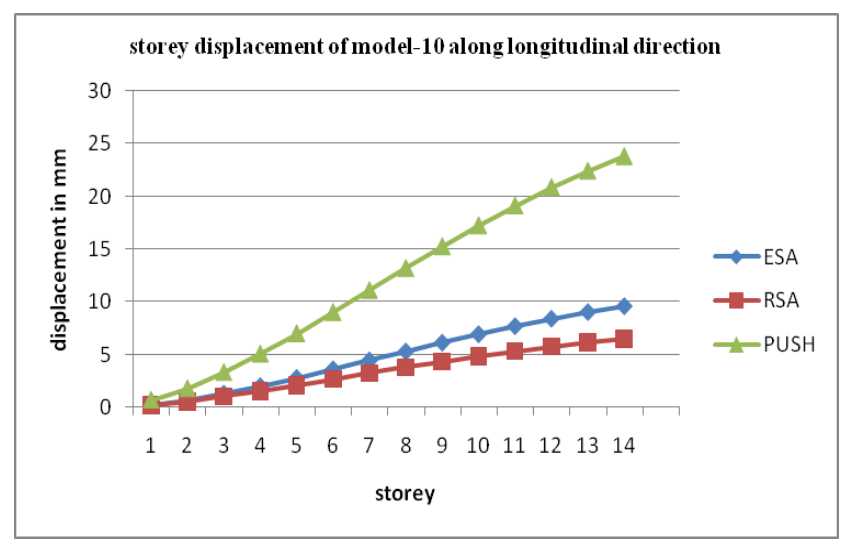

Chart $\mathbf{- 4 3}$

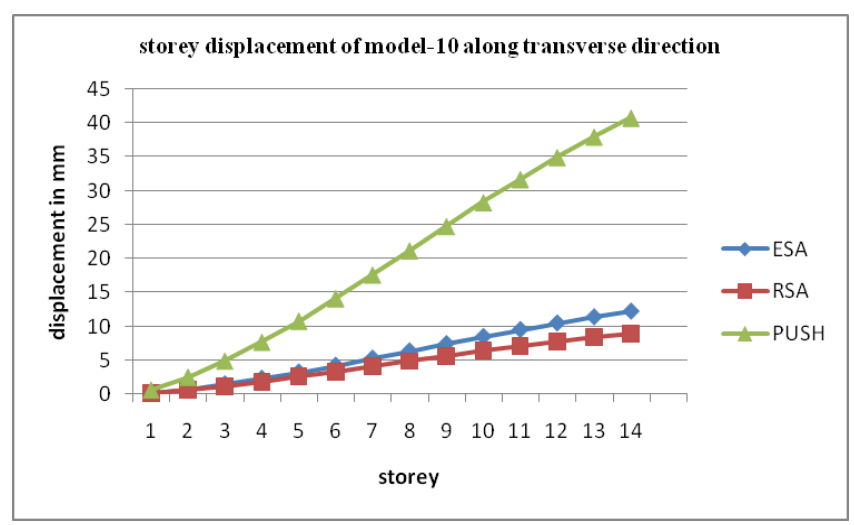

Chart -44 
The bare frame (model 1) yields the higher values of displacement for ESA compared to other methods in which the ESA curve lies above the curves obtained of RSA and Pushover. From the charts 27 to 44, for model 2 to model 10 , it is observed that, the displacement values for models are smaller in comparison to model 1. Also the displacement in the transverse direction is more that the corresponding displacement in the longitudinal direction. Comparing soft storey models i.e. models 3,4,5, 6,7 and 9 with other models with infill it is seen that the displacement values form pushover analysis are less compared to values obtained from ESA and RSA and the curve lies below that of ESA and RSA. Further by providing shear walls in different patterns the displacement values are further reduced. From the above observations we at this position can say that as soon as we see that infill stiffness increases we also see there the displacement decreases.

\subsection{Ductility Ratio ( $\mu$ ) and Response Reduction}

\section{Factor (R)}

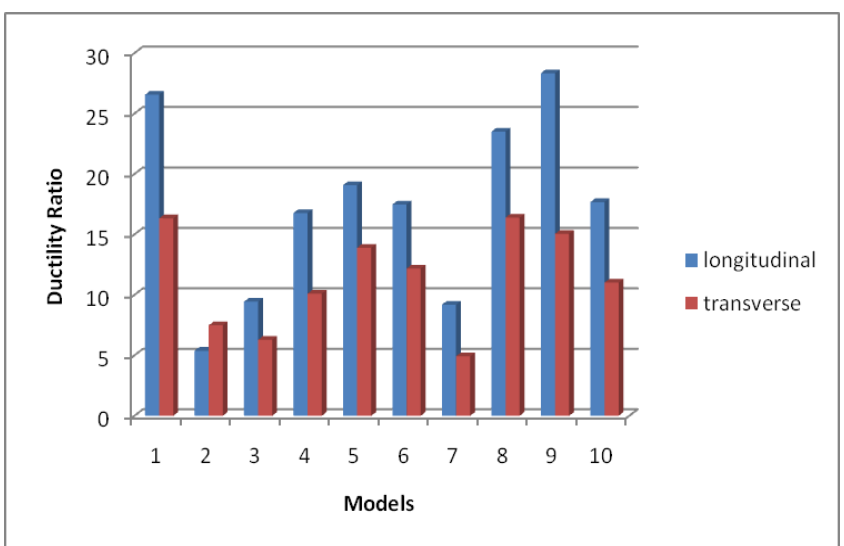

Chart-45 Ductility ratio for all building models in both directions

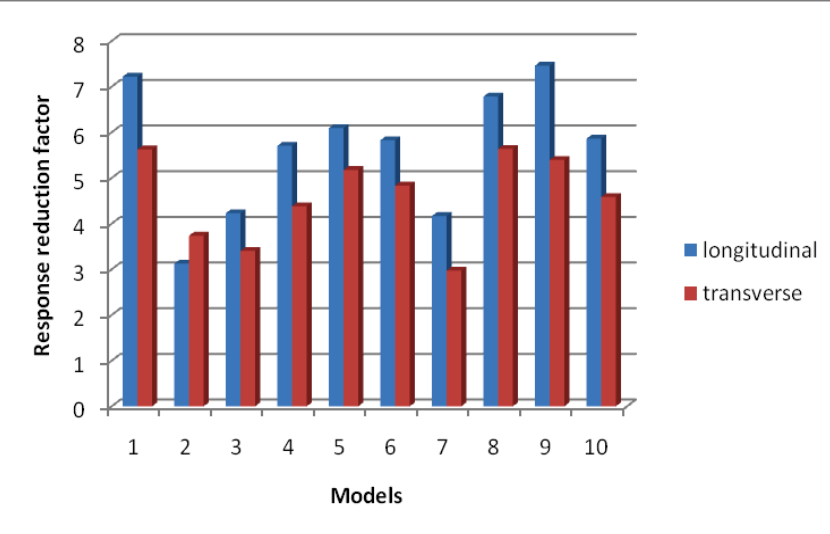

Chart-46 Response reduction factor for all building models in both directions

From the above charts it can be observed that the bare frame model yields highest values for $\mu$ and $\mathrm{R}$ in both directions. whereas comparing the other models, model 10 gives significant values of $\mu$ and $\mathrm{R}$. Hence it can be concluded that as the infill stiffness increases ductility ratio and response reduction factor increases.

\section{CONCLUSIONS}

1. The fundamental natural time period is observed to be the less for the models with full infill as compared to the models with soft storey.

2. It has also been noticed that the time period decreases when the infill walls are included and also when the concrete shear walls are provided.

3. It is seen that By providing the infill the storey drifts and the respective displacement are considerably reduced.

4. In the bare frame the performance level of the building under the study reaches to collapse level denoted by the letter [C]. But as when the performance levels is at immediate occupancy denoted by the letter [IO] to the life safety level denoted by the letter [LS].This implies that the infill has the structure implications and cannot be neglected in the RC buildings designs.

5. The models such as soft basement / soft basement + soft storey there we come to a conclusion that there is a significant decrease in base shear as well as the respective displacement values of soft storey as in comparison to the other storeys.

6. The performance of the building structure is affected directly or indirectly due to the presence of the soft storey. As the initial hinge that is the first hinge is not formed initially in full infilled model as to those compared with the model containing the soft ground and basement.

7. After carrying out the analysis and the results we came the conclusion that the infill walls are solution in order to the reduce drift at the basement,

8. In the case of full infilled model building we came to observe and note that all of the hinges are produced in linked beams therefore which represents the local damages to building structure. But where as in case of the models consisting of the soft ground storey the hinges are formed also in the columns giving rise to the global damages to the structural frames.

9. The response reduction factor denoted by $[R]$ is found to be higher in bare frames as we compared to the infilled frames.

10. From the analytical point of view we came to a conclusion that the ductility ratio value for bare frame is maximum and is reduced as we consider the effect of soft storeys.

\subsection{Scope for Future Study}

1. Further the studies can be done on tall building structures having a definite irregularity in plan as well as in mass and the stiffness.

2. Studies can also be made by providing the duo systems that is the braced wall with the inclusion of shear walls or single system of shear wall by providing the shear wall at other different positions.

3. The ductility can also be enhanced in prolongness by carrying out the study at the beam column junctions. The procedures as prescribed in the FEMA 273 or ATC 40 can also be applied to the other existing buildings for the 
purpose of carrying out the seismic evaluation of the structure.

4. The study can also be extended with various other provisions of utilities such as swimming pools, fitness centres etc.

5. In this study an extension can be made further with the provision of glazed walls at select storeys or the whole building.

6. The study can also be applied for the analysis of the structures located on the sloping grounds in hilly regions/ terrains.

7. The study can be extendable by using the provisions of damping and also the base isolation systems which isolates the building from its foundation during the ground motion.

\section{REFERENCES:}

[1]. F.Hejazi, S.Jilani, J.Noorzaei, C.Y.Chieng, M.S.Jaafar and A.A.Abang Ali, "Effect of Soft Story on Structural Response of High Rise Buildings", IOP Conf. Series: Materials Science and Engineering 17 (2011).

[2]. Sachin.R.Patel and Sumant.B.Patel, "Effect of Brick Infill Panel in Design of High Rise Building", National Conference on Recent Trends in Engineering \& Technology, 13-14 May, 2011.

[3]. Joao Luis Domingues Costa, "Standard Methods for Seismic Analyses", Report By G-Danmarks Tekniske Universitet, R-064, 2003, ISSN 1601-2917, ISBN 877877-129-9.

[4]. NDOT Structures Manual, "Structural Analysis and Evaluation" Chapter 13, September 2008.

[5]. Ashraf Habibullah and Stephen Pyle, "Practical Three Dimensional Nonlinear Static Pushover Analysis", Structure Magazine, Winter, 1998.

[6]. Sarosh H.Lodi, Aslam F.Mohammed, Rashid A.Khan and M.Selim Gunay, "A Practical Guide to Nonlinear Static Analysis of Reinforced Concrete Buildings with Masonry Infill Walls", NED University of Engineering and Technology and University of California, Berkeley. sam Abidi and Mangulkar Madhuri.N, "Review on Shear Wall for Soft Story High-Rise Buildings", International Journal of Engineering and Advanced Technology (IJEAT), ISSN: 2249 - 8958, Volume-1, Issue-6, August 2012. K. Bell and B.J.Davidson, "Evaluation of Earthquake Risk Buildings with Masonry Infill Panels", NZSEE 2001, Conference, Paper No. 4.02.01. Auckland, New Zealand.

[7]. A research work carried out by T.N Brinda and E .Prasanna on "Design and Performance evaluation of Structural Double Glazing Façade Technology."

[8]. ERPCE-2015: Three days national level workshop on "Earthquake Resistant Practices In Civil Engineering" from $9^{\text {th }}$ to $11^{\text {th }}$ March2015 sponsored by the ministry of earth sciences- India and organised by BKIT Bhalki, district:bidar Karnataka state 